\title{
Characteristic of slaughter value and meat quality of three synthetic pig lines
}

\author{
W. Przybylski ${ }^{1 \#}$, D. Jaworska ${ }^{1}$, E. Olczak ${ }^{1}$, I. Namysław ${ }^{1}$, K. Kajak-Siemaszko ${ }^{1}$, \\ V. Santé-Lhoutellier ${ }^{2}$ and S. Niemyjski ${ }^{3}$ \\ ${ }^{1}$ Faculty of Human Nutrition and Consumer Sciences, Warsaw University of Life Sciences - SGGW, Poland \\ ${ }^{2}$ Quality of Animal Products INRA, 63122 Saint Genés Champanelle, France \\ 3 PenArLan, Spółdzielcza 2a Str, 64-100 Leszno, Poland
}

\begin{abstract}
The aim of the study was to evaluate the quality of meat in different lines of pigs with consideration of the intramuscular fat level of the longissimus muscle. The research was conducted on 60 pigs from three pig lines, P76, Redone and Galia, (20 gilts in each group), slaughtered at $c a .105 \mathrm{~kg}$ live weight. The percentage meat in the carcass and hot carcass weight were estimated. Samples were taken from the longissimus muscle. The $\mathrm{pH}$ value after 1,3 and $24 \mathrm{~h}$ post mortem, natural drip loss, cooking yield and parameters of meat colour were measured. Furthermore, fat level and glycolytic potential (GP) of the muscle were determined. Intramuscular fat level was determined chemically, and marbling on the basis of sensory evaluation according to a Japanese photographic standard. The results showed significant differences between lines in slaughter value of carcasses and for $\mathrm{pH}_{3}, \mathrm{pH}_{24}, \mathrm{GP}$, colour parameters and marbling of raw meat. The P76 line was characterised as the most meaty line with satisfactory meat quality. The Redone line was characterised by meat with the highest intramuscular fat content and marbling.
\end{abstract}

Keywords: Meat quality, intramuscular fat, P76, Redone, Galia, swine

${ }^{\#}$ Corresponding author. E-mail: wieslaw_przybylski@sggw.pl

\section{Introduction}

In Europe pork is very important because of the high level of human consumption. Changes in the pork industry are taking place all over the world. Intensive production systems and increased meat production could cause a decrease in sensory and technological (suitability for meat processing) pork quality through the practice of crossbreeding of breeds with a high lean meat content. Average consumer's satisfaction is based on visual impression while purchasing the product (appearance of the product) and then on its sensory quality and culinary usefulness. Research carried out in recent years emphasized that for consumers the sensory quality of culinary meat, which is determined mainly by level of intramuscular fat (IMF) and other traits such as drip loss and the $\mathrm{pH}$ of the meat, is very important. The level of intramuscular fat is dependent on breed, portion of meat in the carcass, slaughter weight and nutrition of the animal during the growing period (De Vries et al., 2000; Rosenvold \& Andersen, 2003). Recent studies highlighted the link between these properties and the level of IMF in meat and marbling. These two traits vary according to breed and environmental conditions. Fat content in muscle tissue influences meat quality significantly, particularly tenderness, juiciness and flavour of meat, and drip loss. Recent studies on crosses between Naïma sows and P76 boars suggested the existence of an intramuscular fat gene in animals where high levels and a high degree of variability of intramuscular fat were observed (Jaworska et al., 2006; Przybylski et al., 2007). The Naïma line is obtained from the crossbreeding of two lines - the Redone (from Tiameslan) and the Galia lines. The Tiameslan line was created by the PenArLan breeding company in collaboration with INRA, by crossbreeding Chinese x European breeds (Zhang et al., 2000).

However, the mechanism of accumulation of fat in muscle tissue is still not fully understood (Roehe et al., 2003). Recently a study by Lian et al. (2007) suggested that a combination of hormones (insulin, somatotropin, epinephrine and glucagon) could increase the IMF content by increasing the fatty acid synthetase (FAS) mRNA expression. The research by Jaworska et al. (2006) and Przybylski et al. (2007), crossing Naïma sows with P76 boars, suggested the possible existence of an intramuscular fat gene in these pigs, since a high degree of variability in intramuscular fat content was observed, which was characterised by a bimodal distribution. A strong relationship was also observed between marbling and drip loss with 
tenderness of cooked meat. The aim of the present study was to evaluate the quality of meat in three genetic lines of pigs, the P76, Redone and Galia lines.

\section{Materials and Methods}

An experiment was carried out on 60 fattened pigs from three pigs line, the P76, Redone and Galia lines, with 20 gilts from each line. The pigs were slaughtered at about $105 \mathrm{~kg}$ live weight. The pigs were produced and reared under the same conditions and were fed a standard diet: A complete mixed diet consisting of cereal with additives - mineral and vitamins. In the first period ( $25-65 \mathrm{~kg}$ body weight) the pigs received the following diet: 13,7 MJ ME, $169.1 \mathrm{~g}$ crude protein and $10.41 \mathrm{~g}$ lysine $/ \mathrm{kg}$. In the second period $(65-105 \mathrm{~kg})$ the finisher diet contained $13.58 \mathrm{MJ} \mathrm{ME}, 155.6 \mathrm{~g}$ crude protein and $9.42 \mathrm{~g}$ lysine $/ \mathrm{kg}$. The animals were slaughtered in accordance with legally binding procedures (the distance from the farm to the slaughterhouse was $200 \mathrm{~km}$, a rest period of about $2 \mathrm{~h}$, automatic electric stunning and exsanguinations in a horizontal position).

After slaughter, backfat thickness and longissimus thickness were measured on a carcass at the height of the last rib ca. $7 \mathrm{~cm}$ from carcass mid-line, using a CGM apparatus (Sydel Corporation, France) (directly on the line or in the meat plant laboratory). On the basis of this measurement meat percentage in a carcass was estimated according to the equation of Borzuta (1998). Meat quality parameters were evaluated (directly on the line or in the meat plant laboratory) in samples of the longissimus muscle taken behind the last rib: The $\mathrm{pH}$ value was measured with a WTW-330i pH-meter at 1,3 and $24 \mathrm{~h}$ after slaughter; meat colour was measured using the CIE $\mathrm{L}^{*} \mathrm{a}^{*} \mathrm{~b} *$ system $(\mathrm{L}$ - lightness, $\mathrm{a}$ - reference to the red, $\mathrm{b}$ - saturation towards the yellow colour) with CR310 Minolta equipment at $48 \mathrm{~h}$ post mortem; natural drip loss (DL) was determined $48 \mathrm{~h}$ after slaughter according to the method described by Prange et al. (1977).

Cooking yield of meat was determined on $500 \mathrm{~g}$ meat samples. The cooking process was conducted to reach $72{ }^{\circ} \mathrm{C}$ inside the meat. The cooking yield was the weight of the cooked meat sample as a percentage of the raw sample. The fat in the muscle was determined according to the Polish- ISO Standard by means of the Soxhlet's method (PN-ISO 1444:2000). Glycogen, glucose and glucose-6-phosphate after glycogen hydrolysis with amyloglucosidase (Dalrymple \& Hamm, 1973) and lactate (Bergmeyer, 1974) in the muscle were also determined. Based on these analyses, the glycolytic potential (GP) was calculated according to Monin \& Sellier (1985).

Sensory evaluation of marbling ( $96 \mathrm{~h}$ after slaughter) was determined on raw meat using the sensory scaling methods (PN-ISO 4121: 1988); [scale 0 - 10 c.u. - conventional unit]. Additionally, the JapaneseCarcass-Grading-Standards (www.blackmorewagyu_com) were applied. For visual assessment raw pork chops were placed on white, disposable polystyrene foam trays. Trays with meat were covered with a polyethylene film, as displayed in supermarkets. Samples were put in a daylight room and analyzed at random.

The statistical analysis of variance was performed using Statistica 6.0 software (StatSoft, Inc., 2001).

\section{Results and Discussion}

The obtained results indicated that line $\mathrm{P} 76$ could be characterised by significantly higher $(\mathrm{P} \leq 0.05)$ meatiness as well as loin thickness in comparison to the Redone and Galia lines. These results confirm that P76 is a good line for crossbreeding with its high meatiness and good meat quality. It was confirmed in the study of Krzęcio et al. (2003) that in crossbreeding P76 boars with Polish Landrace sows the meatiness is similar to results from crossbreeding of Pietrain and Duroc boars with Polish Landrace (about 57\%) sows. In the examined P76 fatteners, neither PSE (pale, soft, exudative) nor acid meat was found. Similar observations were found by Jaworska et al. (2006) for fatteners originated from the crossbreeding of P76 boars with Naïma sows. It was probably a result of the elimination of a stress sensitivity gene and a RN gene from PenArLan herds. Meat from Redone and Galia lines were characterised by a lower $\mathrm{pH}_{3}$ and higher marbling (Table 1). Line Galia was characterised by the highest $(\mathrm{P}<0.05) \mathrm{GP}$ and the lowest $\mathrm{pH}_{24}$ while the Redone line was characterised by the lowest $(\mathrm{P}<0.05) \mathrm{PG}$ and the highest $\mathrm{pH}_{24}$ as well as the highest marbling. The Redone line also had the highest level of IMF and the lowest drip loss, though differences between lines were not statistically significant. Similar results on intramuscular fat were obtained on crossing Naïma sows with P76 boars (Przybylski et al., 2007). 
The results obtained in this work (Table. 1) indicated that the Redone line was characterised by higher $(\mathrm{P}<0.05)$ marbling than the Galia and P76 lines. High variability of the studied meat samples resulted in no significant difference in the level of IMF between lines (high variability in meat samples was mainly observed in the P76 and Redone lines). These differences in IMF level resulted in great variability between results from individuals (Figure 1a). In the case of the P76 line the vast majority of results were below 2\%. As was showed in a study by Przybylski et al. (2007) such a low level of IMF is invisible during sensory analysis (Figure 1b, 1c). Using the sensory analysis as well as the Japanese standard revealed that marbling in the P76 line was significantly lower $(\mathrm{P}<0.05)$ than in the other lines. The Redone line was characterised by a higher mean and greater variability for IMF (Figure 1a) and this caused in higher level of marbling (Figure 1b, 1c). High variability in IMF level in the Redone and Galia lines resulted in the high variability in marbling. However, significant $(\mathrm{P}<0.05)$ differences in marbling of the tested meat samples were obtained. It was observed also that the Japanese standard enabled a more precise discrimination of marbling in the cases of the Redone and Galia lines.

Table 1 Characteristic of slaughter value and meat quality in different genetic pig lines

\begin{tabular}{|c|c|c|c|c|}
\hline \multirow{2}{*}{ Traits } & \multicolumn{3}{|c|}{ Genetic line } & \multirow[b]{2}{*}{ s.e.m. } \\
\hline & P76 & Redone & Galia & \\
\hline Hot carcass weight (kg) & 86.1 & 85.1 & 87.5 & 0.99 \\
\hline Meatiness (\%) & $59.8^{\mathrm{a}}$ & $57.2^{\mathrm{b}}$ & $55.3^{\mathrm{c}}$ & 0.32 \\
\hline Loin thickness (mm) & $65.3^{\mathrm{a}}$ & $57.6^{\mathrm{b}}$ & $52.4^{\mathrm{c}}$ & 0.86 \\
\hline Backfat thickness (mm) & 12.7 & 13.5 & 14.4 & 0.31 \\
\hline $\mathrm{pH}_{1}$ & 6.38 & 6.43 & 6.42 & 0.03 \\
\hline $\mathrm{pH}_{3}$ & $6.31^{\mathrm{a}}$ & $6.12^{\mathrm{b}}$ & $6.18^{\mathrm{b}}$ & 0.02 \\
\hline $\mathrm{pH}_{24}$ & $5.60^{\mathrm{a}}$ & $5.66^{\mathrm{a}}$ & $5.51^{\mathrm{b}}$ & 0.01 \\
\hline Glycolytic potential of longissimus muscle $(\mu \mathrm{mol} / \mathrm{g})$ & $126.8^{\mathrm{a}}$ & $109.9^{\mathrm{b}}$ & $134.4^{\mathrm{a}}$ & 2.44 \\
\hline Intramuscular fat level $(\%)$ & 1.67 & 2.27 & 1.89 & 0.16 \\
\hline Cooking yield (\%) & 72.2 & 72.8 & 71.8 & 0.41 \\
\hline Drip loss $(\%)$ & 3.61 & 2.45 & 3.75 & 0.25 \\
\hline Colour L & $55.67^{\mathrm{a}}$ & $53.95^{\mathrm{b}}$ & $54.04^{\mathrm{b}}$ & 0.26 \\
\hline $\mathrm{a}$ & $15.99^{\mathrm{a}}$ & $15.58^{\mathrm{a}}$ & $17.19^{\mathrm{b}}$ & 0.13 \\
\hline $\mathrm{b}$ & $9.33^{\mathrm{a}}$ & $5.49^{\mathrm{b}}$ & $5.97^{\mathrm{b}}$ & 0.23 \\
\hline Marbling of raw meat (0 - 10 c.u. $)$ & $2.70^{\mathrm{a}}$ & $4.28^{\mathrm{b}}$ & $3.83^{\mathrm{b}}$ & 0.15 \\
\hline $\begin{array}{l}\text { Marbling evaluated according to Japanese standard } \\
\text { (points) }\end{array}$ & $1.25^{\mathrm{a}}$ & $2.24^{\mathrm{b}}$ & $1.48^{\mathrm{a}}$ & 0.07 \\
\hline
\end{tabular}

These results regarding high variability in level of IMF and marbling related to meat quality traits in the Redone line, could indicate that the genetic predisposition of these traits in this line originated from the Tiameslan line that was developed from crossbreeding between Chinese Meishan and European lines. Our results are consistent with the study of Janss et al. (1997), who established a hypothesis about the existence of a main gene (in Meishan crossbreeding pigs) that affects the intramuscular fat content, and thus tenderness of meat and reduced drip loss. Similarly, Sellier (1998) suggested the existence of this gene in the Duroc breed. Sanchez et al. (2003) showed that a major gene had an influence on meat quality in the Tiameslan line. Gerbens et al. (1998) showed significant associations between genetic variation of the adipocyte (A-FABP) and heart (H-FABP) fatty acid-binding protein gene loci and intramuscular fat content in purebred Duroc pigs. Koćwin-Podsiadła et al. (2005), in research conducted on pig populations containing $25 \%$ and $50 \%$ Duroc genes, showed a relationship between polymorphism of the H-FABP gene (identified by endonclease HaeIII) and IMF in the longissimus muscle. Árnyasi et al. (2006) showed an association between the FABP3 gene and IMF in pigs, and in their studied, polymorphism of this gene explained $30-35 \%$ of the variation in IMF. Nechtelberger et al. (2001) did not confirm these results when studying the Large White, Landrace and Pietrain breeds. The results of Li et al. (2006) indicated that the Meishan is 
characterised by only one allele for this gene. The mentioned results indicate that in case of the Meishan breed there is a possibility of the existence of another gene that could influence IMF.

It has been noticed that a higher level of IMF and marbling were related to a lower level of GP. In our study significant negative correlations between GP and intramuscular fat were found $\left(\mathrm{r}=-0.44^{*} ; \mathrm{P}<0.05\right)$. Przybylski et al. (2009) also obtained a similar relationship between IMF and GP $\left(\mathrm{r}=-0.35^{*} ; \mathrm{P}<0.05\right)$. In the studies of Larzul et al. (1998) genetic correlations between GP and carcass slaughter values were observed. The relationship indicated that meatiness was positively correlated with the level of glycogen in the muscle. This indicates that selection aimed at improving meatiness could lead to an increase in the level of glycogen in the muscles. In other studies (Larzul et al., 1995) on selected pigs, a significant decrease in the muscular GP was observed after four generations. In this experiment the indirect relationship on the backfat thickness was also observed. The calculated correlation between these traits was $r=-0.60$. This effect could be confirmed by decreasing of intramuscular fat which has been observed in recent years. The higher level of drip loss in meat could be related to a higher level of GP in muscle.
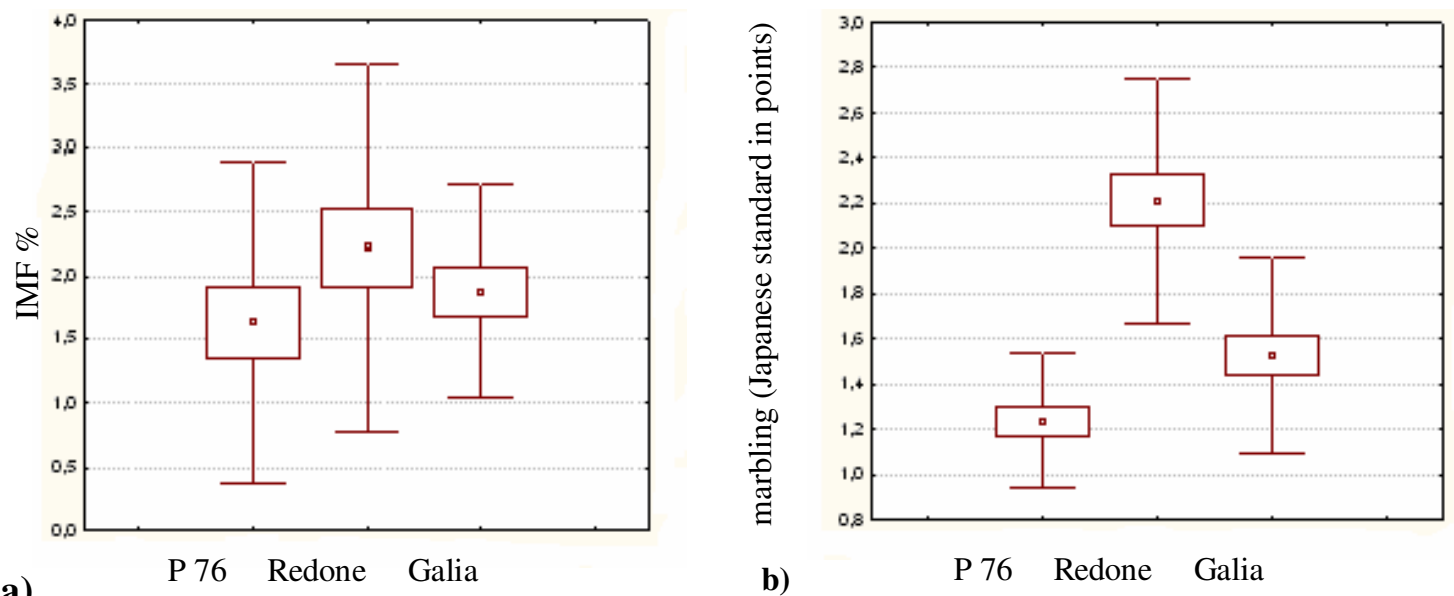

a)

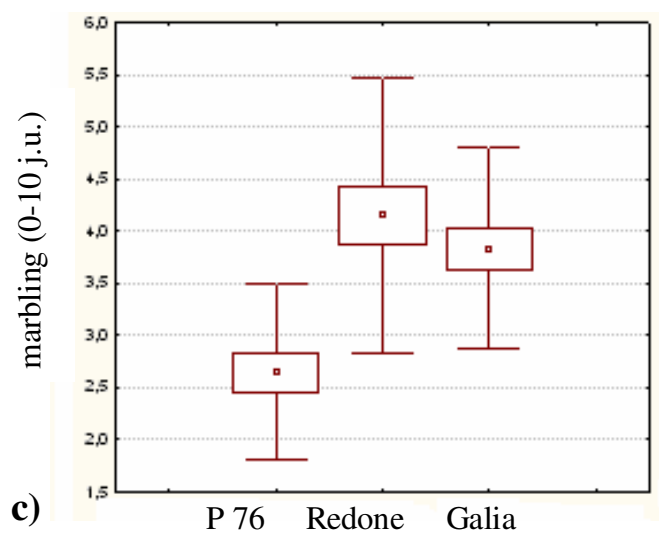

Figure 1a, b, c Distribution of intramuscular fat (IMF) (evaluated by Soxhlet method) and marbling (according to sensory scaling method and Japanese-Carcass-Grading-Standards) in a studied on genetic pig lines.

The colour of meat from the Redone line was darker (lower value of parameter $\mathrm{L}^{*}$ ) and the meat exhibited a lower GP and higher $\mathrm{pH}_{24}$. Darker meat is often found in muscle with limited glycolysis (Swatland, 2004). In case of the Redone line the parameter a* (redness) was similar to that in the P76 line. The parameter $b^{*}$ (yellowness) was similar to that in the Galia line. 


\section{Conclusion}

The results showed significant differences between groups in slaughter value of the carcass and in $\mathrm{pH}_{3}, \mathrm{pH}_{24}, \mathrm{GP}$, colour parameters and marbling of raw meat. The P76 line was characterised as the line with most meatiness while the Redone line was displayed higher marbling and ultimate $\mathrm{pH}$ as well as lower GP and drip loss. The obtained results on the meat quality of the studied lines could be due to differences in the level of marbling and GP since a significant negative relationship between IMF and GP was observed in this study. These results indicate the possible existence of a major gene that influences meat quality in the Redone line that contains genes of Chinese breeds.

\section{References}

Árnyasi, M., Grindflek, E., Javor, A. \& Lien S., 2006. Investigation of two candidate genes for meat quality traits in a quantitative trait locus region on SSC6: the porcine short heterodimer partner and hart fatty acid binding protein genes. J. Anim. Breed. Genet. 123, 198-203.

Bergmeyer, H.U., 1974. Methods of Enzymatic Analysis. Academic Press, New York, pp. 1127, 1196, 1238, 1464.

Borzuta, K., 1998. The study of variable methods usefulness to meatiness estimation in EUROP system. Roczn. Inst. Przem. Mięs 35, 2, 1. (in Polish, English abstract).

Dalrymple, R.H. \& Hamm, R., 1973. A method for the extraction of glycogen and metabolites from a single muscle sample. J. Food Technol. 8, 439-444.

De Vries, A.G., Faucitano, L., Sosnicki, A. \& Plastow, G.S., 2000. The use of gene technology for optimal development of pork meat quality. Food Chem. 69, 397-405.

Gerbens, F., Jansen, A., Van Erp, A.J.M., Hardens, F., Meuwissen, T.H.E., Rettenberger, G., Veerkamp, J.H. $\&$ Te Pas, M.F.W., 1998. The adipocyte fatty acid-binding protein locus: Characterisation and association with intramuscular fat content in pigs. Mamm. Genome 9, 1022-1026.

Janss, L.L.G., Van Arendonk, J.A.M. \& Brascamp, E.W., 1997. Bayesian Statistical Analyses for Presence of Single Genes Affecting Meat Quality Traits in a Crossed Pig Population. Genetics 145, 395-408.

Japanese-Carcass-Grading-Standards, www.blackmorewagyu.com.au/pdf/Japanese-Carcass-GradingStandards. pdf

Jaworska, D., Przybylski, W., Kołożyn-Krajewska, D., Czarniecka-Skubina, E., Wachowicz, I, Trząskowska, M., Kajak, K., Lech, A. \& Niemyski, S., 2006. The assessment of relationships between characteristics determining technological and sensory quality of pork. Anim. Sci. Pap. Rep. 24/2, 121-135.

Koćwin-Podsiadła, M., Krzęcin, E., Kurył, J., Pospiech, E., Grześ, B., Zybert, A., Sieczkowska, H., Antosik, K. \& Łyczyński, A., 2005. Influence of polymorphism of chosen genes on meatiness and selected properties of meat tissue. In: Postępy genetyki molekularnej bydła i trzody chlewnej. (red). M. Świtoński, AR Poznań, Poland. (in Polish, English abstract).

Krzęcio, E., Sieczkowska, H., Zybert, A., Antosik, K., Przybylski, W. \& Kocwin-Podsiadła, M., 2003. Quality of raw material of two-breed fatteners originating from crossing of imported breeds. Annals Anim. Sci., Suppl. 1, 65-69.

Larzul, C., Le Roy, P., Gogué, J., Talmant, A., Vernin P., Lagant, H., Monin, G. \& Sellier, P., 1995. Résultats de quatre générations de sélection sur le potentiel glycolytique musculaire mesuré in vivo. Journées Rech. Porcine en France 27, 171-174. (in French, English abstract).

Larzul, C., Le Roy, P., Monin, G. \& Sellier, P., 1998. Variabilité génétique du potentiel glycolytique du muscle chez le porc. INRA Production Anim. 11 (3), 183-197. (in French, English abstract).

Li, C.L., Pan, Y.C. \& Meng, H., 2006. Polymorphism of the H-FABP, MC4R and ADD1 genes in the Meishan and four other pig populations in China. S. Afr. J. Anim. Sci. 36, 1-6.

Lian, H.X., Lu, D.X., Gao, M. \& Zhang, Y.F., 2007. Influence of hormones on mRNA abundance of fatty acid synthetase in Longissmus dorsi muscle of pigs in vitro. $53^{\text {rd }}$ ICoMST, 219-220 pp.

Monin, G. \& Sellier, P., 1985. Pork of low technological quality with a normal rate of muscle $\mathrm{pH}$ fall in the immediate post-mortem period: The case of the Hampshire breed. Meat Sci. 13, 49-63.

Nechtelberger, D., Pires, V., Soolkner, J., Brem, G., Mueller, M. \& Mueller, S., 2001. Intramuscular fat content and genetic variants of fatty acid-binding protein loci in Austrian pigs. J. Anim. Sci. 79, 2798-2804.

PN-ISO 1444:2000 . Meat and meat products - Determination of free fat content. 
PN-ISO 4121: 1988. Polish Standard. Sensory analysis. Evaluation of food products using scaling methods. Prange, H., Juggrt, L. \& Scharner, E., 1977. Untersuchungen zur Muskel fleischqualitaet beim Schwein. Archives Experim. Vet. Med. 30, 2, 235-248. (in German, English abstract).

Przybylski, W., Kajak-Siemaszko, K., Jaworska, D., Czarniecka-Skubina, E., Wachowicz, I. \& Urbańska, I., 2007. Influence of different level of intramuscular fat on pork quality. Anim. Sci. Vol 1, 112-113.

Przybylski, W., Olczak, E., Gromadzka-Ostrowska, J., Jaworska, D., Niemyski, S. \& Santé-Lhoutellier, V., 2009. Analysis of variability of plasma leptin, lipids concentration in relations to glycolytic potential, intramuscular fat and meat quality in P76 pigs. J. Anim. Feed Sci. 18, 296-304.

Roehe, R., Plastow, G.S. \& Knap, P.W., 2003. Quantitative and molecular genetic determination of protein and fat deposition. HOMO Vol. 54/2, 119-131.

Rosenvold, K. \& Andersen, H.J., 2003. Factors of significance for pork quality - review. Meat Sci. 64, 219-237.

Sanchez, M.P., Bidanel, J.P., Hang, S., Naveau, J., Burlot, T. \& Le Roy, P., 2003. Likelihood and Bayesian analyses reveal major genes, affecting body composition, carcass, meat quality and the number of false teats in a Chinese European pig line. Genet. Sel. Evol. 35, 385-402.

Sellier, P. 1998. Major genes and crossbreeding with reference to pork quality. Pol. J. Food Nutr. Sci. Vol. 7/48, No. 4 (S), 77-89.

StatSoft, Inc., 2001. STATISTICA (data analysis software system), Version 6. www.statsoft.com.

Swatland, H.J., 2004. Progress in understanding the paleness of meat with a low pH. S. Afr. J. Anim. Sci. 34 (Suppl. 2), 1-7.

Zhang, S., Bidanel, J.P., Burlot, T., Legault, C. \& Naveau, J., 2000. Genetic parameters and genetic trends in the Chinese x European Tiameslan composite pig line. I. Genetic parameters. Genet. Sel. Evol. 32, 41-56. 